\title{
Correction to: Recovery of Previously Uncultured Bacterial Genera from Three Mediterranean Sponges
}

\author{
Dennis Versluis $^{1} \cdot$ Kyle McPherson ${ }^{1} \cdot$ Mark W. J. van Passel $^{1,2} \cdot$ Hauke Smidt $^{1} \cdot$ Detmer Sipkema $^{1}$
}

Published online: 26 April 2018

(C) Springer Science+Business Media, LLC, part of Springer Nature 2018

Correction to: Mar Biotechnol (2017) 19:454-468

https://doi.org/10.1007/s10126-017-9766-4

The original version of this article unfortunately contained a mistake. In the "Nucleotide Sequence Accession Numbers" section, the accession number "PRJEB4784" that links to the deposited data is incorrect.

It should be corrected to "PRJEB8621".

The online version of the original article can be found at https://doi.org/ 10.1007/s10126-017-9766-4

Detmer Sipkema

detmer.sipkema@wur.nl

1 Laboratory of Microbiology, Wageningen University \& Research,

Stippeneng 4, 6708 WE Wageningen, The Netherlands

2 National Institute for Public Health and the Environment,

Bilthoven, The Netherlands 